\title{
President's Message: For The Record
}

Aimee Fifarek

This is my final column as LITA President. Having just finished the 2016/17 Annual Report, I must admit I'm a little tapped out. Over the last year I've written on the events of an ALA Annual and Midwinter Conferences, a LITA Forum, a new strategic plan, information ethics, and advocacy. Even for an English Major and a Librarian that's a lot of words.

As I work with Executive Director Jenny Levine and the rest of the LITA Board to prepare the agenda for our meetings at Annual, the temptation is to focus on all the work that is yet to be done. But with the end of school and fiscal years approaching, it is the ideal time to celebrate everything that has been accomplished over the last 12 months.

First off, at some magical point during the year we completed the LITA Staff transition period. Jenny has truly made the Executive Director position her own, and although she and Mark Beatty have more than enough work for six people, they are well on their way to guiding LITA to a bright new future. With her knowledge of the inner workings of ALA and her desire to make everything easier, faster and better, Jenny is truly the right person for this job.

Next, we have a great new set of people coming in to lead LITA. Andromeda Yelton is going to be a fabulous LITA President. She is an eloquent speaker, has more determination than anyone I know, and is a kick ass coder to boot. Bohyun Kim has an amazing talent for organizing and motivating people, and as President-Elect work wonders with the new Appointments Committee. Our new Directors-at-Large Lindsay Cronk, Amanda Goodman, and Margaret Heller are all devoted LITAns who will be great additions to the Board. I'm glad I get to work with them all in their new roles as I transition to Past-President.

And last but certainly not least we have started to make inroads on our Advocacy and Information Policy strategic focus. The Privacy Interest Group has already raised LITA's profile by supplementing ALA's Intellectual Freedom Committee's Privacy Policies with Privacy Checklists. ${ }^{1}$ A group of Board members along with Office for Information Technology Policy liaison David Lee King and Advocacy Coordinating Committee liaison Callan Bignoli are working on a new Task Force proposal to outline strategies for effectively collaborating with the ALA Washington Office. These are just the first steps towards a future in which LITA is not only relevant but necessary.

With all that hard work accomplished, it must be time to toast to our successes. I hope that everyone who will be at ALA Annual in Chicago (http://2017.alaannual.org/) later this month will join us as we conclude our $50^{\text {th }}$ Anniversary year. Sunday with LITA promises to be amazing, with

Aimee Fifarek (aimee.fifarek@phoenix.gov) is LITA President 2016-17 and Deputy Director for Customer Support, IT and Digital Initiatives at Phoenix Public Library, Phoenix, AZ. 
Hugo Award winner Kameron Hurley (http://www.kameronhurley.com) speaking at the President' Program, followed by what is sure to be a spectacular LITA Happy Hour at The Beer Bistro (http://www.thebeerbistro.com/). We are still working on our goal to raise $\$ 10,000$ for Professional Development scholarships. We're only halfway there, so please donate at: https://www.crowdrise.com/lita-50th-anniversary.

Being LITA President during the Association's 50th Anniversary year has been both an honor and a challenge. During a milestone year like this you become acutely aware of all of the hard work and innovation that was required for the Association to thrive for half a century, and feel more than a little pressure to leave an extraordinary legacy that will ensure another fifty years of success. It's a tall order, especially in an era of rapid political and societal change. But as I navigated through my presidential year I realized that I didn't have to do anything more than ensure that people who already want to work hard for the greater good have a welcoming place to do just that.

After fifty years, LITA still has the thing that made it a success in the first place: a core group of volunteers committed to the belief that new technologies can empower libraries to do great things.

The talented and passionate people I have worked with on the Board, in the Committee and Interest Group leadership, and throughout the membership are the best legacy that an Association can have. Now more than ever the people in libraries who "do tech" can be leaders in their communities and on the national stage. Now more than ever it is LITA's time to shine.

\section{REFERENCES}

1. http://litablog.org/2017/02/new-checklists-to-support-library-patron-privacy/ 